\title{
USING ADHESIVE MATTER FOR AGRICULTURAL WASTES AS BUILDING BRICKS
}

\author{
1. Tayel S.A. 2- Khairy M. F. A. 3- EL-Soaly I. S. \\ 4- Moussa A. M.
}

ABSTRACT

This research aims at studying the use of some adhesive materials for rice straw in building bricks. It also studies the physical and mechanical properties of these bricks to know their potential practical use. The study of bricks was evaluated using bulk density, thermal conductivity, acoustic insulation and compressive strength. Two particle sizes (small and large), two formation pressures (1.3 and 2.5 MPa) and three different mixing ratios were chosen for binding material in mixture $(45,60$ and $75 \%)$. The obtained data showed that bulk density increases with increasing binding material percentage. Bulk density was higher at small chops than large chops. The value of thermal conductivity increases with increasing of binding material percentage. The minimum and maximum values of thermal conductivity were $0.077 \mathrm{~W} / \mathrm{m} .{ }^{\circ} \mathrm{c}$ at $1.3 \mathrm{MPa}$ and mixture percentage of $45 \%$ for large chops with By-Pass cement dust, and $0.315 \mathrm{~W} / \mathrm{m} .{ }^{\circ} \mathrm{c}$ at $2.5 \mathrm{MPa}$ and mixture percentage of $75 \%$ for small chops with clay (respectively). Acoustic insulation percentage decreased with increasing binding material percentage for both small and large chops, while minimum and maximum values of acoustic insulation percentage were $4.8 \%$ at $1.3 \mathrm{MPa}$ and mixture percentage of $75 \%$ for large chops with clay, and $10.09 \%$ at $2.5 \mathrm{MPa}$ and ratio of $45 \%$ for small chops with By-Pass cement, respectively. The results of compressive strength test indicated that mixing of small rice straw with By-Pass cement for all ratios at different pressures and mixing of large rice straw with By-Pass cement for ratio of $75 \%$ is accepted as a carrying brick, and also mixing of small rice straw with clay for ratios 60 and $75 \%$ and mixing of large rice straw with clay for ratio $75 \%$ at different pressures is accepted as a carrying brick.

1- Prof. of Ag. Eng., 2- Prof. and head of Ag. Eng., 3- Assoc. Prof. of Ag. Eng., 4- Assist. Lect. of Ag. Eng.,

All the authors are of Ag. Eng. Dept., Fac. of Ag., AL-Azhar Univ. Cairo. 


\section{INTRODUCTION}

$\mathrm{I}$ $n$ the last few years, the problem of crop residues accumulated has become very difficult. Getting rid of crop residues by burning, causes serious problems in air, ground and water pollution. Egypt produces about 30 million tons of crop residues per year, 3 million of which is rice straw (F. A.O. 2003). 90\% of this amount is burned (Nouno, 2003).

There are different means to solve or diminish this problem; as:

1- Using these residues for animal feedings.

2- Using these residues as organic fertilizer.

3- Utilizing these residues in recycling industry as in making paper, pressed wood, packaging and building materials.

Rice straw decomposes in the soil in two stages which means it is highly durable. It was found in a good condition in ancient Egyptians tombs. Thus, theoretically, buildings using rice straw will last for centuries (Nouno, 2003). Furthermore, adding straw to building materials increases heat insulation, so it could be used in farm buildings.

Abd EL- Ghaffar (1987) showed that the methods of residues disposing are:

1- Convert it to rural energy sources by using anaerobic fermentation or heating analysis methods.

For compressed wood industries by using cotton stalks and other some crop residues with high pressure, heat and some binding materials.

2- To improve characteristics of soil by using animal residues and rice straw.

3- It is used as a rural fertilizer and animal forage by using butchery residues in poultry forage industry. The rice straw and other residues were used in animal forage industry.

USDE (1995) said that straw has been used for centuries by builders who recognized its structural integrity. Beside that, a piece of straw is simply a tube made of cellulose. Tubes are recognized as one of the strongest structural shapes. Straw was first used to reinforce mud against cracking. A lattice of straw criss-crossing a layer of mud produced a surface that remained crack free for decades, or in many cases centuries. 
El-Zahaby (1996) used adhesive material (cement) with some field crop residues for production of unconventional bricks and reported that:

1- $100 \%$ cement: the brick of fine ground cotton stalk was better than brick of coarse ground corn stover and the brick of fine ground corn stover was the last.

2- $50 \%$ cement : the fine ground cotton stalks brick was better than the coarse ground corn stover brick or fine ground corn stover brick, the fine ground corn stover brick resistance was approximately equal the coarse ground corn stover.

Noakes (1953) illustrated that the method used to measure the heat conductivity is called less method or lees disc method for measuring the thermal conductivity of a bad conductors. The sample was put between the two disks of brass and measure $T_{1}$ and $T_{2}$ by thermometers. He also reported the following equation:

$$
\mathrm{K}=\mathrm{m} . \mathrm{s}\left(\mathrm{T}_{4}-\mathrm{T}_{3}\right) \mathrm{x} / \pi \mathrm{r}^{2} \mathrm{t}\left(\mathrm{T}_{1}-\mathrm{T}_{2}\right)
$$

Where; $\mathrm{m}$ : mass of brass disk $(\mathrm{kg}) ; \mathrm{s}:$ specific heat for brass material $\left(\mathrm{J} / \mathrm{kg} .{ }^{\circ} \mathrm{C}\right)$;

$\mathrm{t}$ : loosing heat time from $\mathrm{T}_{3}$ to $\mathrm{T}_{4}$ ( $\mathrm{sec}$ ); $\mathrm{x}$ :thickness of sample (m); $\mathrm{T}_{1}, \mathrm{~T}_{2}$ : surface temperatures for sides of brass disks $\left({ }^{\circ} \mathrm{C}\right)$.

Cutnell and Johnson (1995) showed that the decibel (dB) is measurement unit encountered frequently on specification sheets to describe the performance characteristics of receiver's intensity level $\beta$ (expressed in decibels) and defined as follows:

$\mathrm{B}($ In decibels $)=10 \log (\mathrm{I} / \mathrm{Io})$

Where; Io: is the intensity of the reference level to which (I) is being compared and is often the threshold of hearing,

$$
\text { Io }=1.00 \times 10^{-12} \mathrm{~W} / \mathrm{m}^{2}
$$

EL- Hag (1969) studied the mechanical and physical properties of cotton stalks and concluded that stalks mechanical properties are directly dependent on dry matter density and moisture content.

EL- darwish and Awad (1984) illustrated that some building materials as mortar, concrete, bricks and ceramic products have a small tension strength beside its strength to compression. These building materials undergo compression test and it has a valuable for wood than tension. 
Besides, the circular cross section samples were preferred in compression test to achieve arranged stresses in their areas.

Suliman (1985) mentioned that the adobe brick has load strength of about $30 \mathrm{~N} / \mathrm{cm}^{2}(0.3 \mathrm{MPa})$. The advantages of building with adobe are; cheap price, a good insulation for heat and the work does not need skill, and disadvantages are; the moisture effect, it corrodes and crumble rapidly and can not painted except with plaster from clay and wheat straw.

Accordingly, this research aims at studying the using of some adhesive materials for rice straw to use it as a building material in making bricks. It will also study the physical and mechanical properties of these bricks to know their potential in practical use. The characteristics of these bricks were evaluated using bulk density, thermal conductivity, acoustic insulation and compressive strength.

\section{MATERIALS AND METHODS}

The present study was conducted in Ag. Eng. Dept., Faculty of Ag. AlAzhar Univ., Cairo, Egypt. Two types of binding materials namely, bypass cement dust and clay were used with two sizes of rice straw with adding amount of water. Three different mixing ratios were chosen to binding material in mixture (straw, binding material and water). These weight ratios were $45 \%, 60 \%$ and $75 \%$ binding material to mixture. Two levels of formation pressure were used namely: 1.3 and 2.5 MPa. Samples were manually mixed to dry in the air for 21 days. Two particles sizes of rice straw were used in this study, large and small chops. These chops were obtained by using a grinding forage machine. Cylindrical specimens were produced to measure thermal conductivity with inner diameter of $105.4 \mathrm{~mm}$; outer diameter of $110 \mathrm{~mm}$, and length of 210 mm.. Rectangular specimens were produced for other measurements. The pressing mold dimensions were $25 \times 12 \times 10 \mathrm{~cm}$.

\section{- Pressing apparatus:-}

The pressing apparatus was used to produce the samples at different formation pressures, PM (PMa). The technical specification of the hydraulic pressing are (according to manufacturing catalogue): Max Capacity $20 \mathrm{Mg}$; Gauge 0-60 MPa; Resolution of $2 \mathrm{MPa}$ Made by SICMI sa, Trecasali (Parma), Italy (1996). 


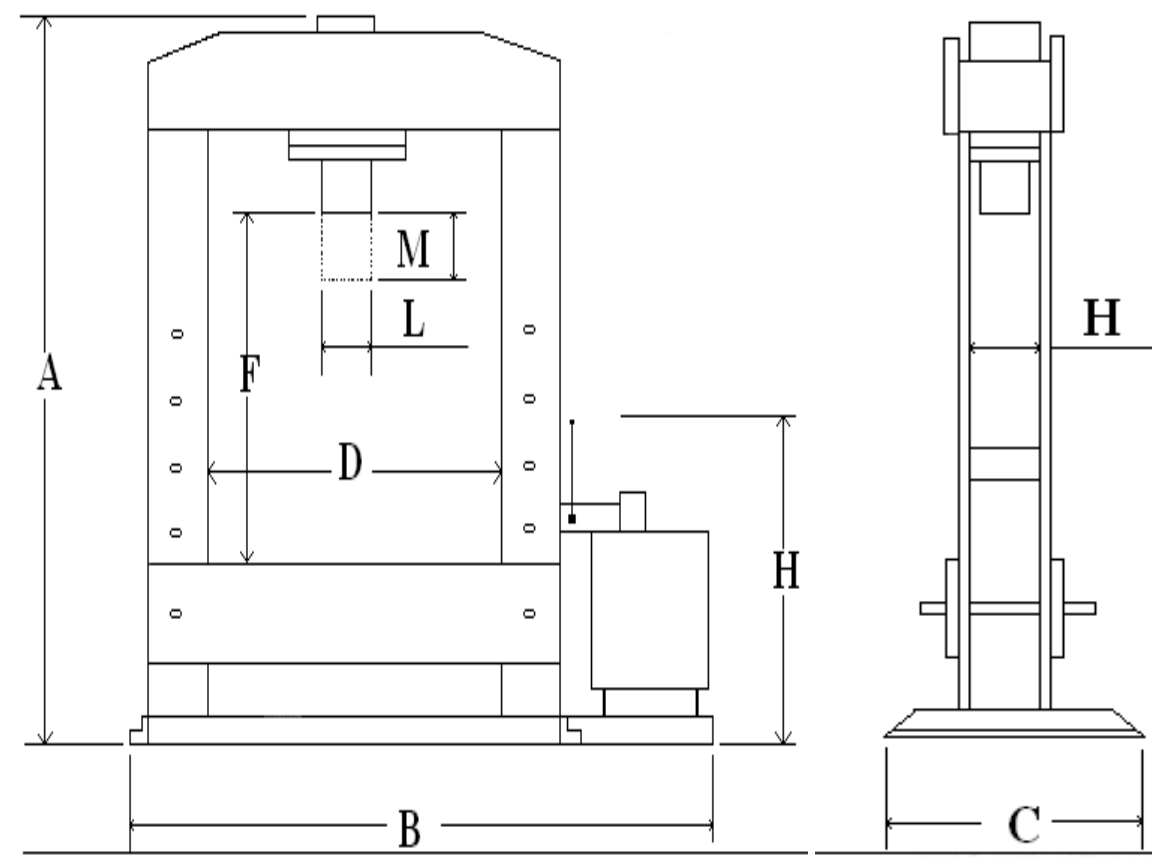

Fig. 3.1: Elevation and side view of pressing apparatus.

Table 3.1: Dimensions of the pressing apparatus in $\mathrm{mm}$.

\begin{tabular}{|c|c|c|c|c|c|c|c|c|c|}
\hline Dimension & A & B & C & D & H & F & H & L & M \\
\hline$(\mathrm{mm})$ & 1950 & 870 & 600 & 600 & 110 & 900 & 900 & 40 & 160 \\
\hline
\end{tabular}

\section{-Acoustic insulation percentage (\%):}

The acoustic insulation percentage "A" (\%) was measured. The source of sound (constant) must be adjusted at a constant level first- This was made by placing the source of sound in opened side of cubic foam and the other opened side was closed by a foam disk. The microphone of digital sound level meter was placed in a foam disk hole then the sound level meter and the source of sound were turned on. To record a sound level with a high constant level of sound, the sound volume bottom was controlled. 


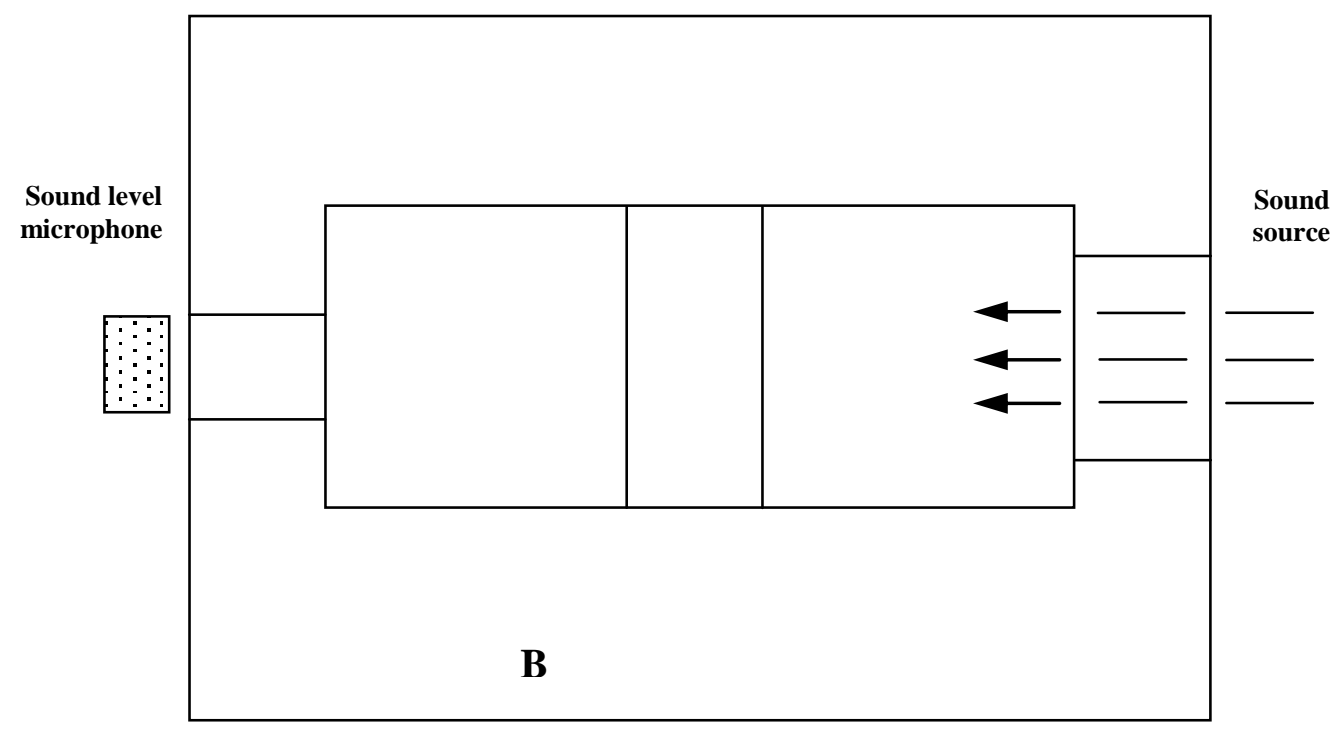

Fig. 3.2: Cubic foam with sample (B).

\section{-Thermal conductivity apparatus:}

A thermal conductivity apparatus was used "K"(W/m. $\left.{ }^{\circ} \mathrm{c}\right)$ of building material samples. An apparatus was developed according to Lees' method (Noakes.,1953). The apparatus was constructed at the workshop of Ag. Eng. Dept., Faculty of Ag. AL-Azhar Un. (EL-Bessoumy,2005).

\section{- Moisture content "MC" (\%):}

Water was added by different quantities based on type of adhesive material and mixing ratio, and measuring moisture content (\%) for mixtures before and after forming pressure.

\section{-Measurements:}

- Bulk density "B.D" calculated by equation:

$$
\text { (B.D.) }=\mathbf{M} / \mathbf{V}
$$

where; M: mass of sample, $\mathrm{V}$ : volume of specimens.

-Acoustic insulation "Ai" was recorded by a digital sound level. It was $110 \mathrm{~dB}$ and multiplied by 100 to give the acoustic insulation percentage "A" (\%) and so on for all specimens.

- Compressive strength was calculated as follows:

$$
\boldsymbol{\delta}=\mathbf{F} / \mathbf{A}
$$

where; F: force $(\mathrm{kN}), \mathrm{A}$ : specimen surface area $\left(\mathrm{m}^{2}\right)$. 
- Moisture content was determined according to the standard ASAES358.2 DEC93(ASAE standard year book,1993).

\section{RESULTS AND DISUSSION}

Physical and mechanical properties of rice straw-bonding materials bricks at this work were studied at different sizes of residue (large chops "L"and small chops "S"), types of bonding materials, formation pressures "FP" (MPa) and mixing ratio (\%).

\section{1-Bulk density:}

Fig. 4.1 show the relationship between bulk density and three binding materials percentages for bricks at the two different pressures for small and large rice straw chops. Results indicated that bulk density increases with increasing binding material percentage and increases with increasing formation pressure for both small and large chops. These results were expected because the pressure affected on the volume of specimens. The values of bulk density were higher at small chops than large chops, This may be because the small chops can compact easier than large chops with adhesive materials and have less pores. The minimum value of bulk density was $0.529 \mathrm{~g} / \mathrm{cm}^{3}$ at $1.3 \mathrm{MPa}$ and ratio of $45 \%$ for large chops with clay, the maximum value of bulk density was $1.307 \mathrm{~g} / \mathrm{cm}^{3}$ at $2.5 \mathrm{MPa}$ and ratio of $75 \%$ for small chops with clay. These values of bulk density lead to classify these bricks according to (interbuild specification encyclopedia 2003) as a medium class weight. The standard bulk density of cement- bricks were of 1.2 to $1.5 \mathrm{~g} / \mathrm{cm}^{3}$ and sand-bricks were of 0.6 to $0.65 \mathrm{~g} / \mathrm{cm}^{3}$.

These results indicate that the bricks made using the rice-straw, are in the acceptable range of two standards and could be considered as an advantage. 


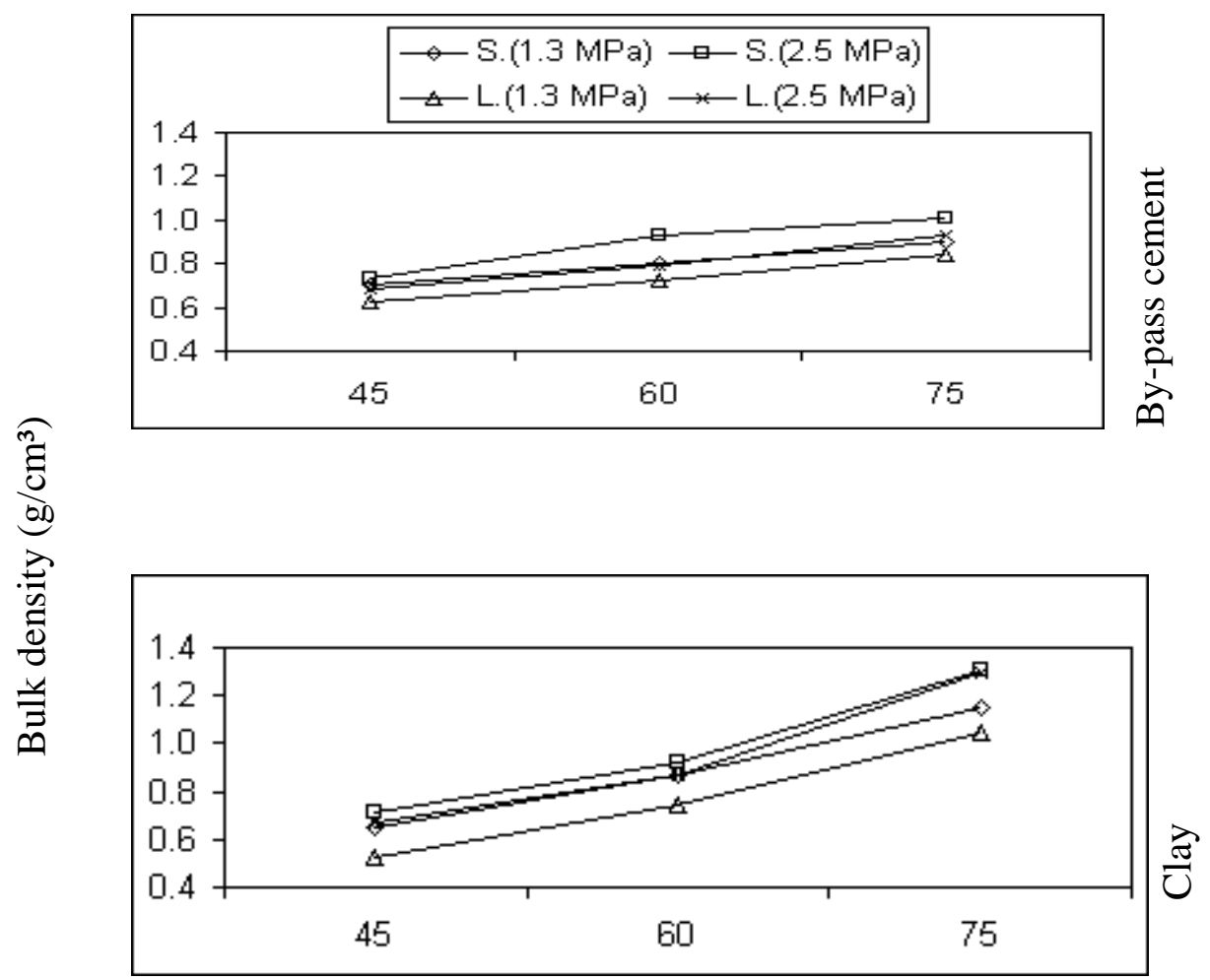

Binding material (\%)

Fig. 4.1. Relations between bulk density $\left(\mathrm{g} / \mathrm{cm}^{3}\right)$ and binding materials ratios $(\%)$ in brick at different forming pressures (MPa) for rice straw chops.

\section{2-Thermal conductivity:}

Fig. 4.2. Illustrate the relationship between thermal conductivity " $\mathrm{k}$ " and three binding materials percentages for bricks. Thermal conductivity increased with the increase of binding material percentage and increased with increasing formation pressure for both small and large chops. The minimum value of thermal conductivity was $0.077 \mathrm{w} / \mathrm{m} .{ }^{\circ} \mathrm{c}$ at $1.3 \mathrm{MPa}$ and ratio of $45 \%$ for large chops with By-Pass cement, the maximum 
value was $0.315 \mathrm{w} / \mathrm{m} .{ }^{\circ} \mathrm{c}$ at $2.5 \mathrm{MPa}$ and ratio of $75 \%$ for small chops with clay. These results show that these bricks have good heat insulation compared to other bricks. For example, sand-bricks have thermal conductivity of 0.27 to $0.34 \mathrm{~W} / \mathrm{m}^{\circ} \mathrm{c}$ (Interbuild specification encyclopedia, 2003).

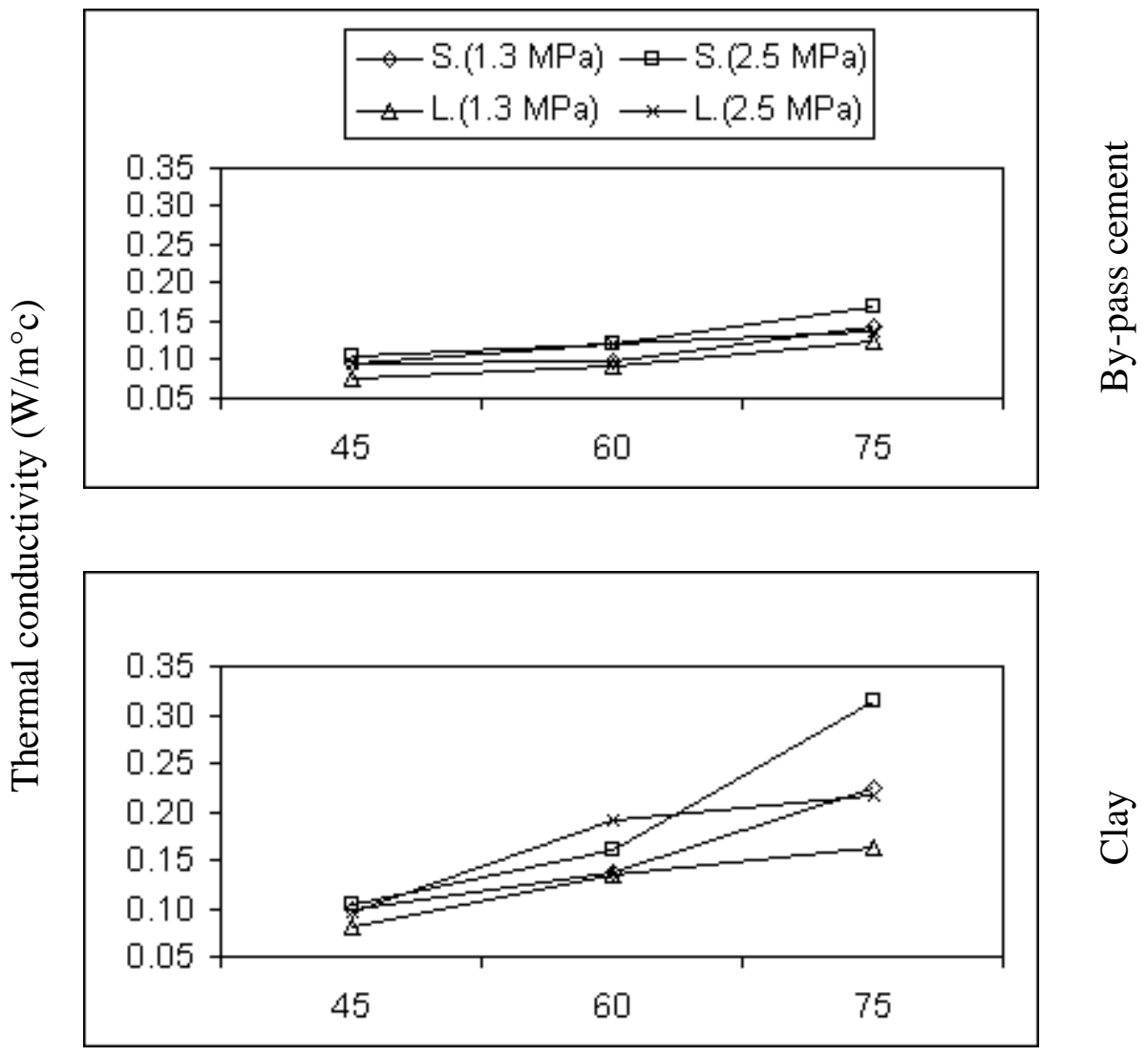

Binding material (\%)

Fig. 4.2. Relation between Thermal conductivity $\left(\mathrm{W} / \mathrm{m}^{\circ} \mathrm{c}\right)$ and binding materials ratios (\%) in brick at different forming pressures (MPa) for rice straw chops.

\section{3- Acoustic insulation:}

Fig. 4.3 illustrate the relationship between acoustic insulation percentage "Ai" (\%) and binding materials percentage for bricks at two different pressures and three mixing ratios for small and large chops of rice straw. Acoustic insulation percentage increases with the decreasing binding 
material percentage for both small and large chops and increases with increasing formation pressure for both small and large chops. The minimum value of acoustic insulation percentage was $4.8 \%$ at $1.3 \mathrm{MPa}$ and ratio of $75 \%$ for large chops with clay, the maximum value was $10.09 \%$ at $2.5 \mathrm{MPa}$ and ratio of $45 \%$ for small chops with By-Pass cement.

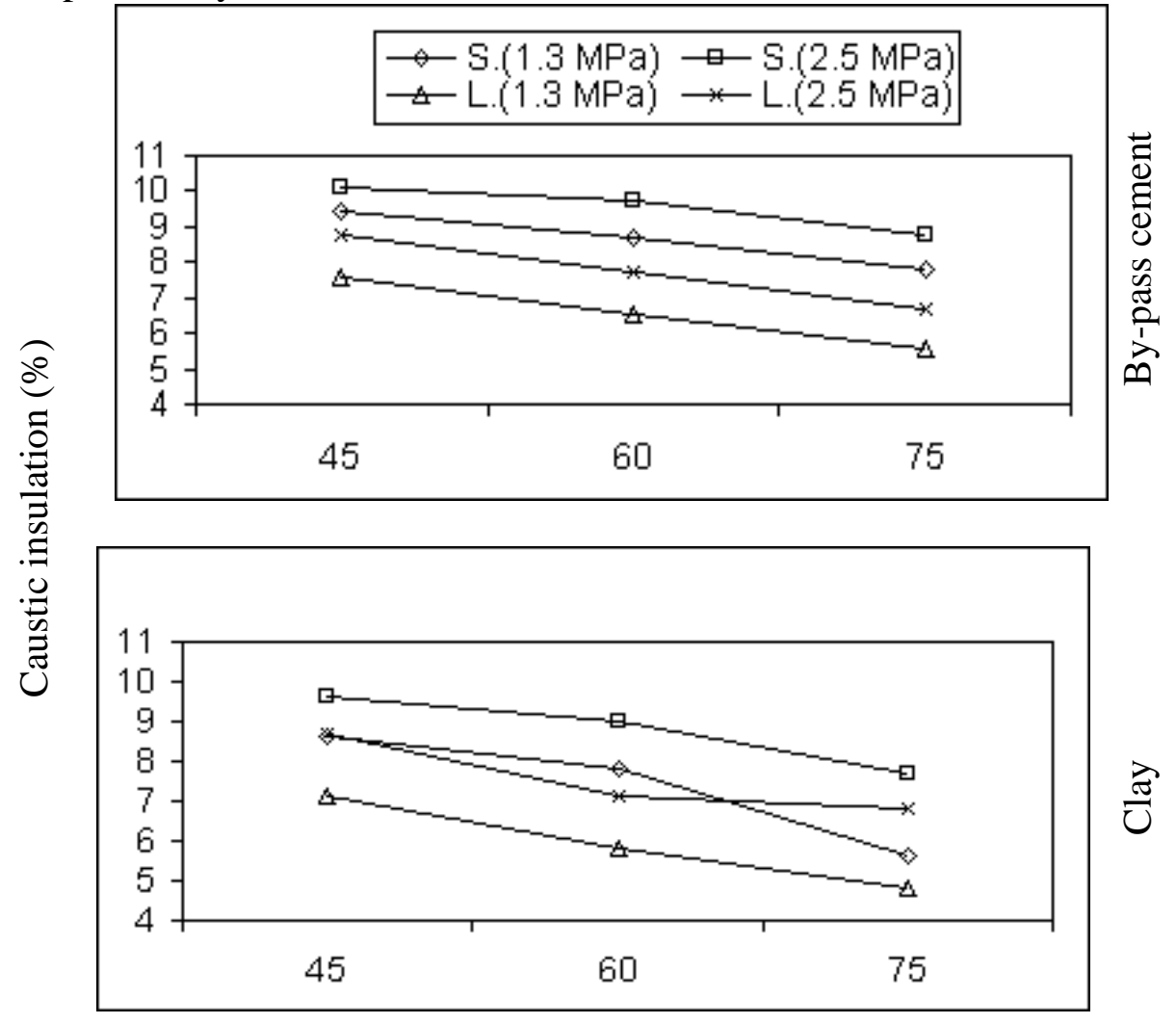

Binding material (\%)

Fig. 4.3. Relation between acoustic insulation (\%) and binding materials ratios (\%) in brick at different forming pressures $(\mathrm{MPa})$ for rice straw chops.

\section{4- Compressive strength:}

Compressive strength is considered the main factor in choosing brick in buildings. Fig. 4.4 show the relationship between compressive strength $\left(\mathrm{kN} / \mathrm{cm}^{2}\right)$ and binding materials percentage for bricks at the two different pressures and three mixing ratios for small and large chops of rice straw. 
Increasing binding material percentage increases compressive strength significantly, and increasing formation pressure increases compressive strength significantly for both small and large chops. The values of compressive strength were higher at small chops than large chops. The

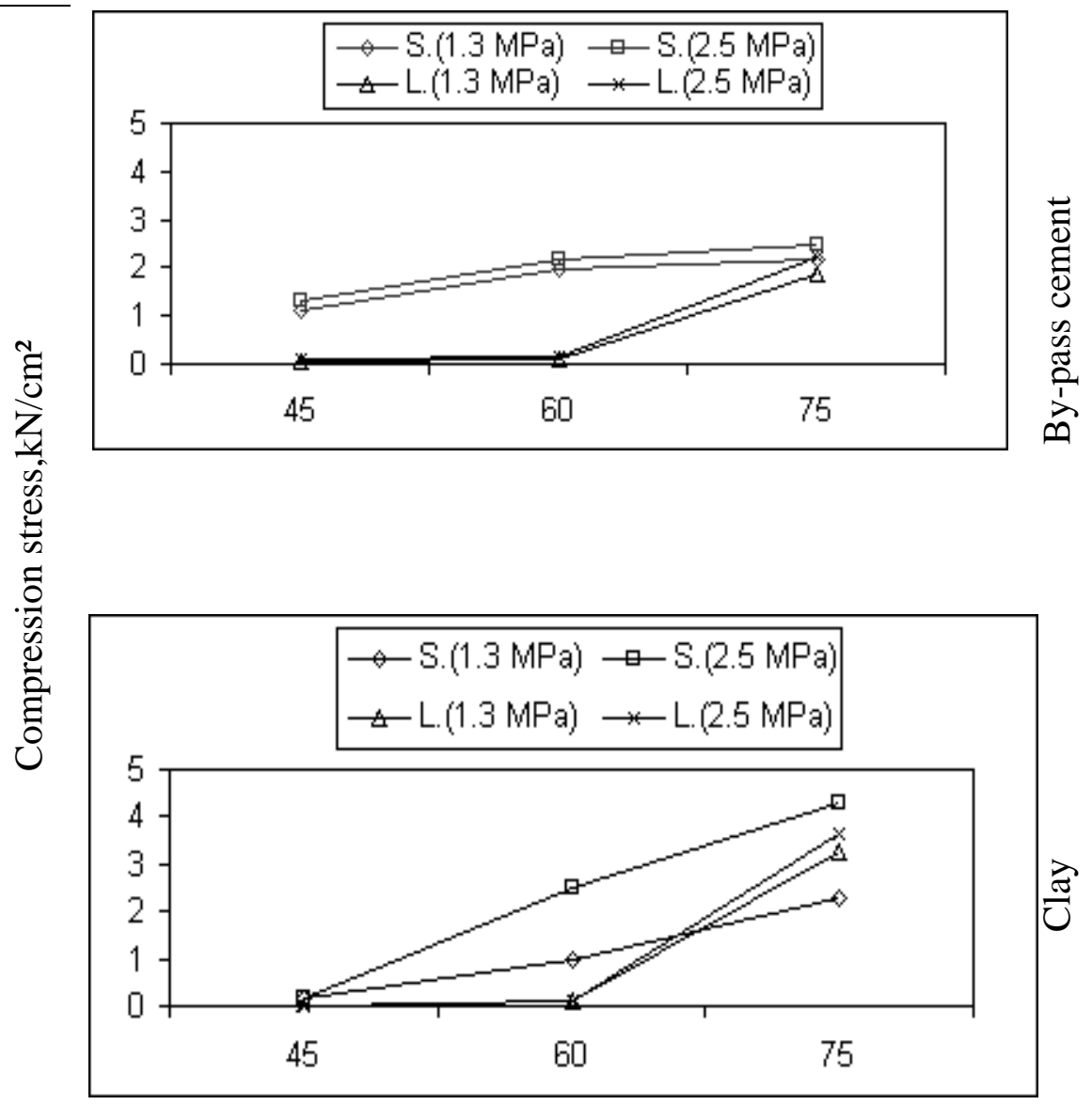

Binding material (\%)

Fig.4.4. Relation between compression stress $\left(\mathrm{kN} / \mathrm{cm}^{2}\right)$ and binding materials ratios (\%) in brick at different forming pressures (MPa) for rice straw chops.

minimum value was $64.2 \mathrm{~N} / \mathrm{cm}^{2}$ at $1.3 \mathrm{MPa}$ and ratio of $45 \%$ for large chops with by-pass cement, the maximum value was $4.28 \mathrm{kN} / \mathrm{cm}^{2}$ at 2.5 $\mathrm{MPa}$ and ratio $75 \%$ for small chops with clay. Egyption standard specification number 1349-1991 indicated that the compressive strength 
of cement-sand brick should not be less than $700 \mathrm{~N} / \mathrm{cm}^{2}$ for carrying bricks and not less than $250 \mathrm{~N} / \mathrm{cm}^{2}$ for uncarrying bricks. Based on this fact, mixing of small rice straw with by-pass cement for all ratios at different pressures and mixing of large rice straw with by-pass cement for ratio of $75 \%$ are accepted as carrying bricks, and also mixing of small rice straw with clay for ratios 60 and $75 \%$ and mixing of large rice straw with clay for ratio $75 \%$ at different pressures are accepted as carrying bricks.

\section{CONCLUSION}

From the previous results, it is concluded that:

- Increasing of binding material percentage and formation pressure lead to increased bulk density, and the bulk density was higher at small chops than large chops.

- Increasing of binding material percentage and formation pressure lead to increased thermal conductivity.

- Increasing of formation pressure lead to increased acoustic insulation for both small and large chops, and increasing binding material percentage lead to decreased acoustic insulation percentage for both small and large chops.

- The results of compressive strength test indicated that the mixing of small rice straw with by-pass cement for all ratios at different pressures and mixing of large rice straw with by-pass cement for ratio of $75 \%$ are accepted as carrying bricks, and also mixing of small rice straw with clay for ratios 60 and $75 \%$ and mixing of large rice straw with clay for ratio $75 \%$ at different pressures are accepted as carrying bricks.

\section{REFERENCES}

Abd EL-Ghaffar, E. A., (1987). Planning of agricultural structures, $1^{\text {st }}$ Ed., El- Shahby Center for Pub and Distribution, Alex, ARE:390 (in Arabic).

Abd El-Mageed, H. N., (1981). Studies on utilization of cotton stalks in Manufacturing woods, M.Sc. Th, Fac. Ag., Mansoura Uni.:2,7,55,56,127,128. 
Abd EL-Rahim, Y. M. S. Houszyyin, and I. S. Taha, (1981).Dimensional analysis and wafering cotton stalks, Trans. of the ASAE,24 (4): 829-832.

Cutnell, J. D. and W. K. Johnson, (1995). Physics, $3^{\text {rd }}$ ed. John Wiley \& Sons, Inc, N.Y.:103.

EL-Darwish, E.A.and A.M.Awad,(1984). Strength and testing of materials, $1^{\text {st }}$. Ed, Dar EL-Rateb AL-Jameya, P.0195229, Beirut, Lebanan: 502 (in Arabic).

EL-Hag, H. E.,(1969).Machanical and physical properties of cotton stalks, Unpub Ph. D. Disser, Taxas A\& M U (c.f. Abd EL- Rahim, et al., 1981).

EL-Zahaby, M. A., (1996).Techno-economic study on utilization of some field crop residues, M. Sc., Th, Ag. En., Faculty of Agric.,Cairo Univ. 2-10. 218-223 (in Arabic).

English, B., P. Chow; and D. S.Baiwa, (1997).Processing in composites,Ch8. paper and composites from agro- based resources.

Joes, B.,(2001).Information guide to straw bale building, Amazon Nails, Hollinroyd Todmordeu,01148J,

WWWstraw bale futures.Org. UK.

Kumar, K. S. and R. P. Lottman,(1972). Using straw to reinforce rigid Urethan foam, J. Ag. Eng., 45-45.

Mohsenin, N. and J., Zasker,(1976). Stress-relaxation and Energy Requirements in compaction of unconsolidated materials, Agr. Eng. Res. 21 (2) : 193-205.

Noakes, G. R., (1953). Text-Book of heat, Macmilan and Co., Liwrrled, London,:337-338.

Nouno, S. (2003). A local professor wants to turn Cairo's burning rice fields into building panels. http://www. businesstodayegypt. com / issues / 0209/ 3E09/ 02093 E09p.asp.

Suliman,A. E.,(1985). Agricultural buildings, booklets, Agr. Eng. Dep., Fac. Ag., Cairo Univ. Egypt lect:120 (in Arabic). 
USDE (Department of Energy),( 1995). House of straw, straw bale construction Comes of age, Office of Building

Technology, State and Community programs, WWW. straw bale control. com or WWW.green builder- com / down.

Zein Eldin, A. M. and S. S. Sadaka, (2000). Cement- agro waste bricks strength and its technical assessment, Misr. J. Ag. Eng. 17 (2) : 266- 285 .

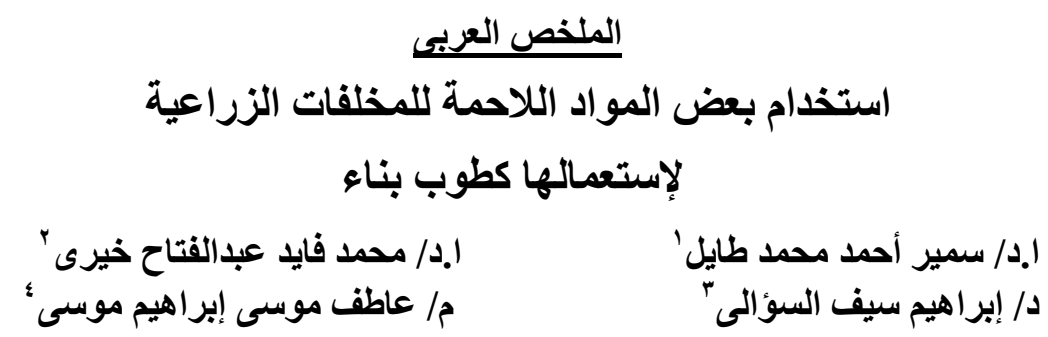

تم در اسدة استخدام قش الأرز فى صسورتين مختلفتين ( قطع كبيرة وقطع صسخيرة) بعد إضـافة

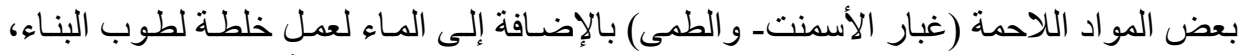

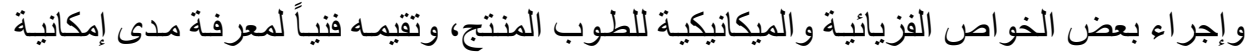

استخدامه فى الحياة العملية. حيث أجريت المعاملات و الاختبار ات الآتية على الخلطة:

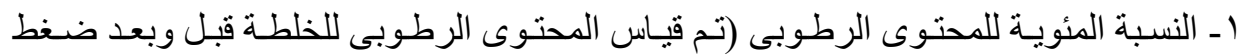

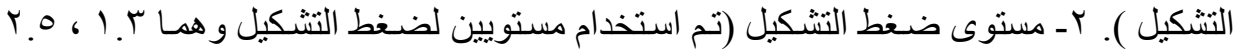

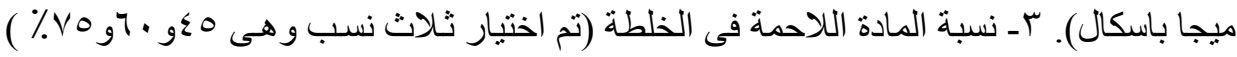

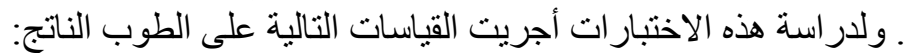

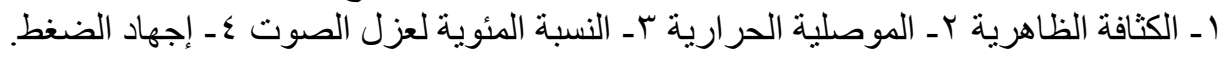

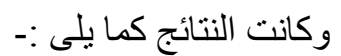

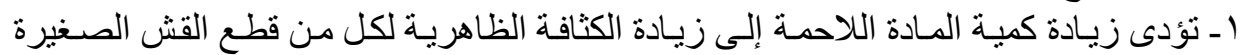

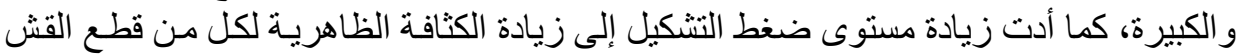

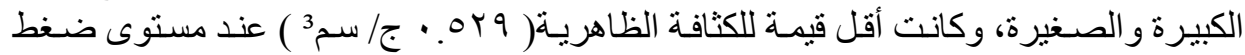

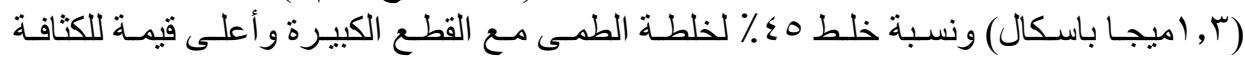

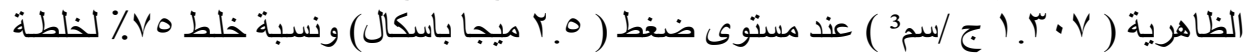

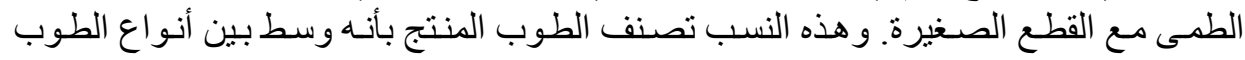

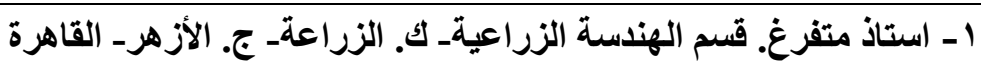

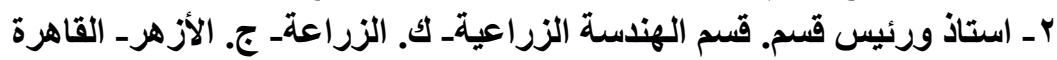

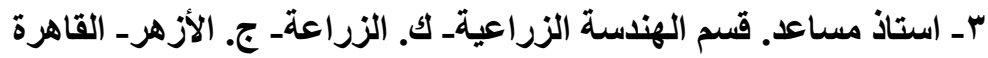

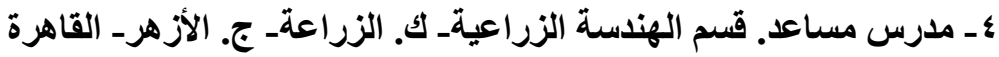


rـ تؤدى زيادة كمية المادة اللاحمة إلى زيادة الموصلية الحر اريـة (انخفاض العزل الحرارى)

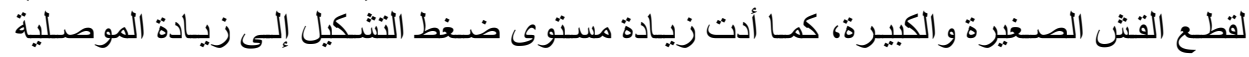

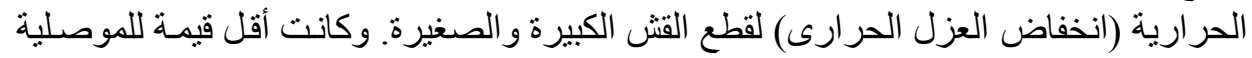

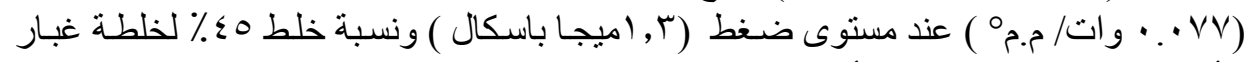

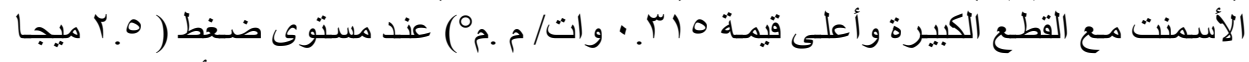

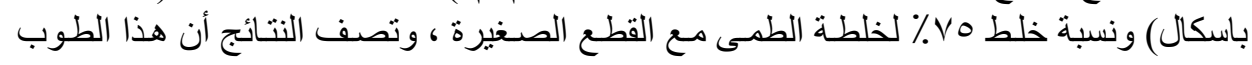

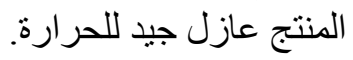

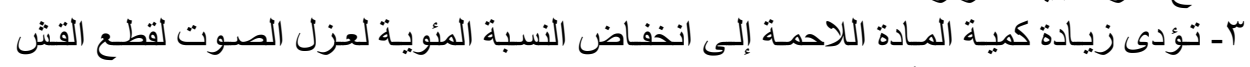

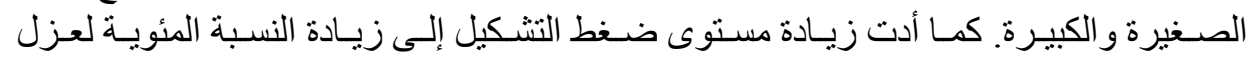

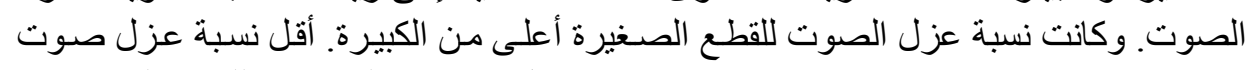

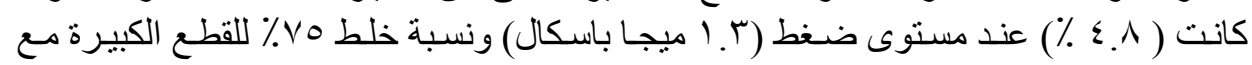

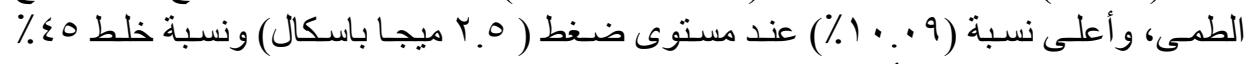
للقطع الصغيرة مع غبار الأسمنت.

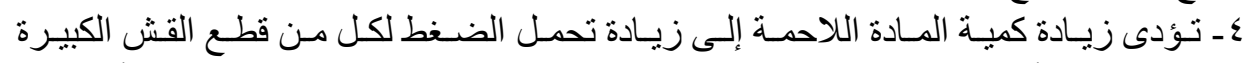

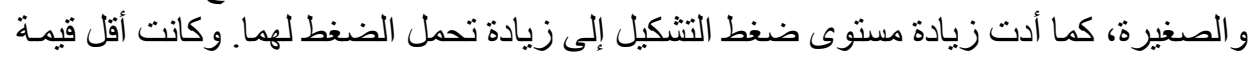

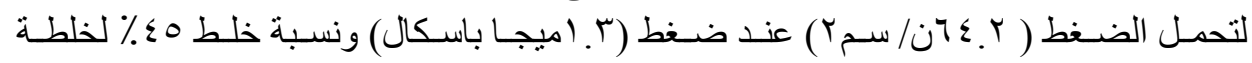

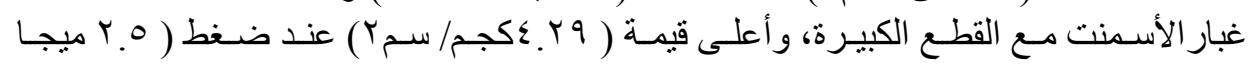

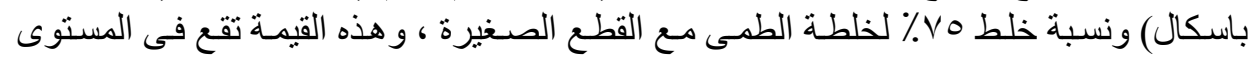
الموصى بـاه. 